\title{
THE CONCEPT OF AL-QUR'AN AND ISLAMIC LAW IN EDUCATING WIFE AND THE SOLUTION FOR DISPUTE SETTLEMENT IN HOUSEHOLD VIOLENCE
}

\author{
Asep Habib Idrus Alawi \\ STAI Shalahuddin Al Ayyubi Jakarta \\ Email: rianto.msi23@gmail.com
}

\begin{abstract}
:
This article discusses the concept of al-Qur'an and the Islamic law in educating wives as well as solutions to the resolution of domestic violence. By using the survey literature method in classical books and using a textual approach to the Law Number 23 of 2004 concerning the Elimination of Domestic Violence, this article found that the husband's obligation to give lessons to his wife was when the wife began to disobey and show nushuz to her husband. Giving these lessons is carried out in sequence, namely: first, the husband is obliged to give a warning to the wife gently and gently as he reminds him to fear Allah. If the wife is obedient again, then the lesson is enough just to get there; second, if the wife is still defiant, leave the wife alone, leaving her in bed, do not engage in conjugal relations. If he is obedient, then the lesson is enough to get there; third, if the wife continues to disobey, then the wife may be 'hit' with a note that is not hard and does not cause injury; punches that can be likened by educating ten-year-old when leaving prayer.
\end{abstract}

Keywords: educating the wife; household disputes; domestic violence;

\section{A. INTRODUCTION}

The concept of family life in Islam places all family members in a portion and position in accordance with each other's nature (Robila \& Taylor, 2018, p. 385). The husband as the head of the family has greater rights than the wife in accordance with his obligations which indeed occupy the most positions (Sondy, 2013, p. 48). Likewise, a wife has the same rights and obligations in accordance with her nature as a woman (Hasan, 2004, p. 31). A child also has the right to be loved but also has an obligation to respect parents (Yarsley, 2014, p. 57). A housemaid has the right to get a decent wage, to do work in accordance with his ability also must follow the rules set by his employer as long as it does not conflict with the teachings of religion and applicable legislation(Menendez, 2013, p. 13). This proportionality as illustrated by the general hadith is achieved by the following history of ibn Umar:

"From Ibn Umar ra, he said: I heard the Messenger of Allah. Say: Every one of you is a leader and will be held accountable for the leadership, an imam is a leader and will be held accountable for his people, a man is a leader in his family and will be held accountable in his family, a woman is a guard in her husband's household and will be held accountable in its care, and an assistant is the guardian of his master's property and will be held responsible for his guardianship. Each of you is a leader and will be asked for responsibility in his leadership. [Narrated by Bukhari (al-Bukhari, 1998, p. 483) and Muslim (alMubarakfury, 1999, p. 246)].

Based on the generality of the hadith, it can be understood that each family member has the same rights and obligations and responsibilities in accordance with their respective portions and positions. Not justified when asking for treatment that exceeds these rights and obligations (Mardani, 2016, p. 3). Among the rights of a husband is to get respect and proper obedience from the family member with regard to the role of a head of the household and must be responsible both morally, materially and spiritually in upholding the teachings of God Almighty. Therefore, a husband's obligations include matters of a nature ukhrawi worldly and spiritual material (Daly, 1988, p. 236). 
The obligation of a husband who is material in nature is to provide a decent living according to the size of his ability to the child, his wife and family members who are his dependents. Not feasible according to the size of the community where he lives (Yarsley, 2014, p. 17). This includes food and clothing. His mental spiritual obligation is to provide guidance to his wife and children and other family members to always obey Allah's commands and His apostles. Including the moral obligation of a husband is to give a warning and even a proper and educational sentence for members of his family who violate God's rules and His apostles (Stiles, 2009, p. 139).

A husband was obliged to 'beat' his nushuz wife (Browning, Green, \& Jr, 2006, p. 198) and his beloved son after he was ten years old and he had carried out his obligation to teach prayers since the child was seven years old (Starrett, 1998, p. 103). A wife has the right to get inner income from her husband (Rheinstein \& Glendon, 1980, p. 81) and has the right to get self-protection and honor from her husband, including getting an education that is in accordance with her husband's ability if he still needs it. While the obligation is to obey the husband both with willingness or with compulsion as long as her husband is still standing in the corridors of the pleasure of Allah Almighty. And a wife is obliged to be an assistant to the husband when the husband is not in his home (Voorhoeve, 2012, p. 99).

The urgency of this study is the generalization of the word "violence" in the household, so that the violence in the household should not occur at all even though the violence is a form of implementing the responsibility of the family (read: husband) in carrying out their obligations to maintain family rails in the line of pleasure of Allah SWT.

This is where an in-depth analysis of domestic violence is needed, whether all types of violence must be abolished without the explicit line that a husband may be assertive and act violently against violations of the sharia that occur in the household according to his authority or obligation.

While Islamic law is not intended to be empty, it is full of wisdom from a law. Between the wisdom of allowing a husband to 'give a lesson' to his wife is so that the wife is always in the husband's control in order to obey Allah Almighty and His Apostles. This is intended to avoid nushuz and the symptoms that lead to it.

\section{B. METHOD}

This article was written by elaborating on the explanations contained in the classical books, whether contained in the Tafsir, Hadith and the opinion of scholars. Interpretation is also done by looking at law No. 23 of 2004 concerning the Elimination of Domestic Violence, coupled with the results of contemporary studies related to domestic violence, both from a number of books and journal articles.

\section{RESULT AND DISCUSSION}

\section{The concept of Nusyuz in the Qur'an}

The root of the word nushuz (n-sh-z/j - ن - ن ) relates to something that rises. Most of mufassirun generally understand women's nushuz as recalcitrance (Ali, 2006, p. 76), disobedience or rebelliousness ('isyan) toward their husbands. Two behaviors are repeatedly cited as forms of nushuz, namely: (1) leaving the marriage house without permission; and (2) rejecting the husband's sexual offer. More rarely, disrespect, obscenity, or failure to carry out religious obligations are referred to as female forms of nushuz (Ali, 2016, p. 120).

Contemporary mufassirun is somewhat different in their interpretation of nushuz. In general, they view nushuz as a type of disharmony in marriage. When a woman does nushuz, most of traditional fuqaha agree on several steps that the husband can use. In addition to those approved by the Qur'an, discussed below, legal experts generally agree that a man can delay his wife's support (nafaqah) if she rejects him and / or leaves home, because she has made herself unavailable to him (Ali, 2016, p. 120). 
Islamic law in addressing the issue of domestic violence focuses more on the problem of nusyuz between husband and wife and the problem of children who are accustomed to not performing prayers; a 10-yearold child after being taught prayer by his guardian since he was seven years old. The crackdown from husbands on helpers for example due to the reckless actions of the servants has not yet been obtained as a reference to be analyzed in Islamic law as long as it is not a criminal offense which is handled by the authorities. Regarding nushuz, the verse 34 of Al-Qur'an, al-Nisa' states:

The man (husband) is the leader of women, because Allah has exaggerated a portion of them (men) over the other (women), and because they (men) have spent part of their property. a godly woman, who obeys God and takes care of herself when her husband is not there, because God has cared for them. the women you worry about nushuz, then advise them and separate them in their beds, and beat them. then if they obey you, then do not look for a way to trouble it. Allah is Most High, Most Great.

Regarding the verse, Tafseer Jalalain explained that men are leaders, namely those who control women, give lessons and protect them, because of what Allah has surpassed, to some of them over some others, such as the advantages in terms of knowledge, reason and guardianship, etc., and the assets they spend (al-Suyuti, n.d., p. 86). Furthermore, it was explained that righteous women are those who obey their husbands, take care of themselves and their honor when their husbands are absent, because Allah Almighty has guarded them by giving them to their husbands. As for the women who are feared to do nushuz, namely immorality to their husbands by disobeying their commands, then advise them to be afraid of Allah, and separate beds, i.e. move to another bed if they are still doing nushuz, and beat they with punches that don't hurt if they separate from sleep they haven't returned to doing good. If they have returned to do what the husband ordered, then do not look for ways to beat him to do persecution.

Completing the explanation above, al-Jurjawi affirms the following matters; the obligation to give a lesson to his wife is when he starts disobeying and demonstrates nushuz to his husband (al-Jurjawi, n.d., p. 43). So, the husband is obliged to give a lesson, but giving the lesson is carried out in sequence, first the husband is obliged to give a warning to the wife gently and gently as he reminds him to fear Allah, if the wife is obedient again, then only enough there. If it is still defiant, then leave the wife alone, leaving her in bed, not gathering her, especially when her lust rises. If she is obedient, then just get there and gather the wife as before. But if it remains, then the wife may be 'beaten' with a note that is not too hard and does not cause injury.

He further explained that by being beaten the wife was still defiant, so it was reported to the competent authorities, in this case to the religious court to appoint hakam or the peacemaker between the two husband and wife parties to reconcile both. As explained in verse shiqaq. The verse 35 of Al-Qur'an states as follows:

And if you are worried that there will be a dispute between the two, then send a hakam [reconciler interpreter] from a male family and a hakam from a female family. if the two hakam were intended to make repairs, God would have given the husband and wife peace. Verily Allah is All-Knowing, All-Knowing.

According to al-Jurjawi, that is the law of Allah Almighty which has been outlined in this issue of nushuz. By understanding the two scholars' analysis above, it can be understood that the beating of a husband to a nusyuz wife is more in the form of the husband's obligation to educate his wife to always obey Allah, not an act of violence that must be abolished. Because thus sunnatullah in a household life as a husband and wife likened to an ark where the husband as his captain and his wife as na'ib to form a family that is sakinah mawaddah wa rahmah will be achieved. Unlike the case with freedom that is propagated by nonMuslims where it is more aimed at crashing the sunnatullah so that the society formed is a society that is free of value and is free from freedom, liberty (al-Jurjawi, n.d., p. 43).

Regarding the problem of 'beating' a father or father or who is a guardian because a child does not want to perform prayers even though he is ten years old and has been prayed by his guardian since the age of seven years, this can be analyzed through the Prophet's hadith as follows: 
a. From 'Amr ibn Syua'ib, from his father, from his grandfather, he said: The Messenger of Allah said: Command your children to pray when they are seven years old and beat them when they leave prayer when they are ten years old. And separate brand beds (male and female). Narrated by Abu Dawud (Abu Dawud, 1997, pp. 237-239).

b. From Abi Tsurayyah Sibrah ibn Ma'bad al Juhani ra. He said, the Messenger of Allah said: Teach a child to pray when he is seven years old and beat them when leaving the prayer after being ten years old. Narrated by al-Tirmidhi (al-Tirmidhi, 1417, p. 111).

Based on the two hadiths above the obligation to teach prayers to Muslim children is charged to both parents starting from the age of seven years old and monitored in the implementation of the prayers so that if he is ten years old, then if the child is negligent to pray then his parents, in this case his father was obliged to give a lesson to him by 'hitting' that was not hard and did not cause scars, which was intended so that he would pay more attention in carrying out prayers (Fuller, 2011, p. 40).

Parents must familiarize their children with prayer and teach their laws and ethics, They, both fathers and mothers, must educate their children and teach thaharah (purification) and prayer to their children, and may beat them if they do not pray when they have reached 'aqil baligh (adult according to the figh/ jurisprudence), with a measure for boys is to have had a wet dream or a daughter who has menstruated or even is fifteen years old (Jalil, 2010).

In the author opinion, "hitting" is one way to educate only if it brings benefits or prevents the bad - done after being given advice and guidance. Therefore, the "hitting" is only an instrument in educating with the assumption that there is certainty of change towards improvement, in addition to the certainty of the absence of injuries resulting from the blow, including the prohibition of hitting the face. The most important thing is that parents must be able to educate their children as best they can, without being fixated by instrumented methods, as mentioned earlier (Sayeed \& Prakash, 2013).

The obligation to hit is intended as a means of education and tahdzir (scare) so that the child will be a person who is used to leaving prayers until his later days. So, basically the command is to be careful that something that is not desired (leaving the prayer) occurs when it has fallen taklif (command to work on the sharia) to the child. The two texts are ordered to hit, both in the case of a nushuz wife or a child who is accustomed to leaving prayer, even though he is still ten years old are the texts which are sharia instructions and can be categorized as the qat'iy al-dilalah texts (Tamam, 2017, p. 94). So that the legal instructions for the text should not be reinterpreted, but must be carried out as directed. Because by itself it is not an ijtihad application field.

However, the forms of beating must be implemented. Because the word "fadlribu" in both texts is a general word, and therefore an explanation is needed so that it is not misunderstood in the implementation later. With regard to the form of beating in the case of nusyuz, there is a hadith narrated by al-Tirmidhi as follows:

From 'Amr ibn al-Ahwas, he heard the Messenger of Allah (peace be upon him) say ... : if she (the wife) is nusyuz then leave in bed and beat with a blow that does not hurt, if he is obedient to you, then do not seek a way to persecute him.Narrated by al-Tirmidhi (al-Tirmidhi, 1417, p. 276).

By using takhshis method for this hadith, it is clear that the blow allowed in the case of Nusyuz is a blow that does not cause injury and especially serious injury. Another case with a blow that must be carried out against a ten-year-old child who leaves the prayer, then it is clearly only an educational and frightening blow, yet at this age if he has not been baligh he has not been subject to taklif. So that in his later days he became a person who was very concerned about prayer thanks to the habit he had instilled since he was just tamyiz. 
The other forms of violence that might occur in a family are beyond the scope of this analysis. To discuss this, there is a need for an in-depth study of Law. 23 of 2004 concerning the Elimination of Domestic Violence (Undang-undang PKDRT) after excluding the two forms of 'violence / entrenchment'. This needs to be reaffirmed so that there is no counter-productive between Law No. 23 referred to in article 29 paragraph 2 of the Body of the Constitution. 1945, where each citizen is guaranteed his freedom to carry out his religious teachings. Article 29 paragraph 2 of the Constitution. 1945 states:

The State guarantees the independence of each resident to embrace his own religion and to worship according to his religion and belief.

In the opinion of the author, the assertiveness of a husband in taking action against his nusyuz wife and child who leaves prayer is one of the forms of freedom to practice religious teachings guaranteed by article 29 paragraph 1 of the Body of the Constitution. 1945.

\section{Settlement of Domestic Violence Disputes According to the Law}

Domestic violence is an action that results in the physical (Shipway, 2004, p. 86), psychological (Brown, McKeon, \& Duau, 2014, p. 25) and sexual misery and suffering of women, including the threat of certain acts, coercion or elimination of arbitrary independence both in public and in the personal life environment (Baderin, 2006, p. 109). The form of rape in the name of a marriage bond or in the position of a perpetrator who is violent with violence or the threat of violence against victims for sexual relations where at that time the victim does not want it is one form of domestic violence (Statsky, 2012, p. 507).

The notion that domestic violence is a household cause arises among husband and wives (RakovecFelser, 2014) whose legal relationship between individuals occurs because in marriage is the scope of civil law. Thus, if there is a violation in the legal relationship between these individuals, law enforcement is carried out by filing a lawsuit by the party who feels disadvantaged. The Law on Marriage does not regulate sanctions that can be imposed on perpetrators of domestic violence (Colker, 2006), such as public law (criminal law).

The problem of violence or abuse that occurs in the household in Law Number 1 of 1974 concerning Marriage is only one reason for the termination of a marriage, as stipulated in Article 38 of the Marriage Law and Article 19 Government Regulation Number 9 Year 1975 concerning Implementing Regulations on Marriage Law Number 1 of 1974.

Through civil law instruments, in this case Law Number 1 of 1974 concerning Marriage, the perpetrators of domestic violence cannot be punished because law enforcement can only be done by filing a lawsuit from the party who feels disadvantaged (Hasanah, 2013). As long as those who experience violence in the household do not feel disadvantaged by domestic violence, a claim will not appear in court. In contrast to using public law that has the nature of violating the law, law enforcement is carried out by the authorities because the purpose of public law is to serve the public interest .

A wife who experiences abuse from her husband, and she wants to file a divorce lawsuit with her husband, then he filed a lawsuit through the Religious Court. In this case, the Religious Court is an institution that has the authority to try certain cases it receives, is a Toy, in accordance with the general explanation of Law Number 7 of 1989 concerning Religious Courts number 2, the third paragraph which reads: The Religious Court is the first level court to examine, decide, and settle cases between people who are Muslim in the field of marriage, inheritance, will, grant, sadaqah based on Islamic law.

Acts of domestic violence in the Religious Courts are only the reason for the trial not to be sporadically investigated by criminal acts of violence (Arifin \& Santoso, 2016). This has been going on for a long time and has caused gender injustice, because usually those who carry the risk of suffering are women, while 
men as perpetrators of violence only get divorce claims which consequently only divorce their wives (Muhajarah, 2016).

Efforts to regulate domestic violence into legislation have been carried out through Law Number 23 of 2004 concerning the Elimination of Domestic Violence. These laws include efforts to prevent, cope with and reduce acts of violence or crime that are increasingly prevalent in the family environment. This is in line with one of the goals of forming a household or family is to form a happy household. If the household is happy, then the environment of certain communities and nations is happy and becomes peaceful. Therefore, understanding and implementing the law is a must.

The law is a demand of the community that has been in accordance with the objectives of Pancasila and the 1945 Constitution to eliminate all forms of violence on Indonesian soil, especially domestic violence. In addition, it is also in accordance with the United Nations Convention which was ratified by the Indonesian government through Law Number 7 of 1984 concerning the Elimination of Discrimination against Women.

Furthermore, Yusdiani stated that the birth of Law No. 23 of 2004 concerning the Elimination of Domestic Violence (UU PKDRT) is a reflection of the social demands that require this law to be born and this law as well as recognition that practices of violence in the household constitutes respect for human rights (HAM). Fear, injustice and discriminatory treatment experienced by women (wives) in the household for the treatment of torture by husbands is a basic human right that must be legally protected (Yusdani, 2011, p. 11).

Thus, there appears to be a change in the views of the government regarding violence occurring in the household, not merely a private matter, but also a public problem (Paymar, 2000, p. 11). In Indonesia, fthis case arises from domestic matters in marriage law that are regulated within the scope of civil law to public legal matters, which is regulated through the Elimination of Domestics Violence (UU PKDRT) (Affiah, 2017, p. 215).

However, the issuance of Law No. 23 of 2004 concerning the Elimination of Domestic Violence (UU PKDRT) will not necessarily meet the expectations of women who are as big as victims of violence in obtaining justice, given the condition of law enforcement in our country that is still far away out of hope and can not be separated from practices that are discriminatory and more beneficial to those who have power, both economic, social and cultural power.

The inclusion of domestic violence into the complaint offense requires the activist of the justice seeker (victim) to complain about the perpetrator to the legal apparatus, while the other side of the victim wants to divorce the perpetrator and the victim must sue the Religious Court, so the victim must litigate the two courts Each event is even though the legal subject is one, but according to the Law the object must be distinguished and processed in two courts (Helmi, 2015).

The need for litigation in two courts according to the author's attention resulted in the failure of one of the important principles of Justice, namely simple, fast and low-cost judicial principles, even though this principle was mandated by Law Number 7 of 1989 regulated in Article 57 paragraph (3) basically this principle is derived from the provisions of Article 4 paragraph 2 of Act Number 14 of 1970.

Domestic violence that has occurred in the community has been going on for a long time. The UN Declaration ("A/RES/48/104. Declaration on the Elimination of Violence against Women," 1993) concerning the elimination of violence against women divides violence against women based on the scope of the occurrence of three forms of violence, namely family violence; violence in society; and violence in the country. This article will only review the issue of domestic violence or who are more familiar with the term domestic violence (domestic violence), especially through the domestic violence legislation process. 
From description above, domestic violence is interpreted to include only the abuse of a husband against his wife because the victims of domestic violence are more experienced by wives than other family members. Domestic violence can take the form of: 1) physical abuse (such as punches, kicks); 2) psychological or emotional persecution (such as threats, insults, ridicule); 3) financial persecution, for example in the form of forced expenditure allotment from a husband; and 4) sexual abuse (forced sexual relations). Whereas in the Domestic Violence Law Domestic violence is all physical, psychological and / or sexual acts that can cause misery to someone, including acts of coercion or deprivation of liberty against the law in the household environment. This study needs to examine more in the process of establishing the Domestic Violence Law. and the review of articles that have been formulated into laws in Law Number 23 of 2004 concerning PKDRT.

As explained above, domestic violence is one of the causes of divorce in the Religious Court. The Religious Court as an institution that handles divorce cases is demanded to resolve divorce cases, one of the reasons being domestic violence. Therefore, this research is intended to determine the role of religious courts in resolving cases of domestic violence in the perspective of Islamic family law in Indonesia.

\section{CONCLUSION}

The obligation to give a lesson to his wife is when he starts disobeying and demonstrates nushuz to his husband. So the husband is obliged to give a lesson, but giving the lesson is carried out in sequence, first the husband is obliged to give a warning to the wife gently and gently as he reminds him to fear Allah, if the wife is obedient again, then only enough there. If it is still defiant, then leave the wife alone, leaving her in bed, not gathering her, especially when her lust rises. If he is obedient, then it is enough to get there and gather the wife as before. But if it remains, then the wife may be 'hit' with a note that it is not too hard and does not cause injury. After a long struggle, the end of 2004 was a historic moment. Because on September 22, 2004 Law Number 23 Year 2004 concerning the Elimination of Domestic Violence was promulgated. Since then, cases of violence that have taken place within the household are no longer processed according to the regulations contained in the Criminal Code, but are dealt with under the special law. With the hope that justice seekers feel more cared for and protected by law.

\section{References:}

Abu Dawud, al-S. (1997). Sunan Abi Dawud (Vol. I). Bayrut: Dar Ibn Hazm.

Affiah, N. D. (2017). Potret Perempuan Muslim Progresif Indonesia. Jakarta: Yayasan Pustaka Obor Indonesia.

al-Bukhari, M. b. I. (1998). Sahih al-Bukhari. Riyad: Bayt al-Afkar.

al-Jurjawi, A. A. (n.d.). Hikmat al-Tasyri' wa Falsafatuhu. al-Qahirah: Jami'ah al-Azhar.

al-Mubarakfury, S. al-Rahman. (1999). Minah al-Mun'im fi Sharh Sahih Muslim (Vol. III). Riyad: Dar alSalam.

al-Suyuti, J. al-Din. (n.d.). Tafsir Jalalain (Vol. I). Bandung: al-Ma'arif.

al-Tirmidhi, M. b. 'Isa. (1417). Sunan al-Tirmidhi. Riyad: Maktabah Ma'arif.

Ali, K. (2006). Sexual Ethics and Islam: Feminist Reflections on Qur'an, Hadith and Jurisprudence. London: Oneworld Publications.

A/RES/48/104. Declaration on the Elimination of Violence against Women. (1993). Retrieved January 29, 2019, from http://www.un.org/documents/ga/res/48/a48r104.htm

Arifin, B., \& Santoso, L. (2016). Perlindungan Perempuan Korban Kekerasan Dalam Rumah Tangga

Perspektif Hukum Islam. De Jure : Jurnal Hukum dan Syari'ah, 8(2), 113-125.

Baderin, M. A. (2006). Islam and Human Rights: Advocacy for Social Change in Local Contexts. Delhi: Global Media Publications. 
Brown, L., McKeon, M., \& Duau, F. (2014). Stop Domestic Violence: An Action Plan for Saving Lives. New York: St. Martin's Press.

Browning, D. S., Green, M. C., \& Jr, J. W. (2006). Sex, Marriage, and Family in World Religions. New York: Columbia University Press.

Colker, R. (2006). Marriage Mimicry: The Law of Domestic Violence. Willi Am \& M Ary L Aw R Evie W, 47(6), 1841-1898.

Daly, P. (1988). Hukum perkawinan Islam: suatu studi perbandingan dalam Kalangan Ahlus-Sunnah dan Negara-negara Islam. Jakarta: Bulan Bintang.

Fuller, C. (2011). When Children Pray: Teaching Your Kids to Pray with Power. Colorado Spring: Crown Publishing Group.

Hasan, A. G. (2004). The Rights and Duties of Women in Islam. Riyad: Darussalam.

Hasanah, H. (2013). KEKERASAN TERHADAP PEREMPUAN DAN ANAK DALAM RUMAH TANGGA PERSPEKTIF PEMBERITAAN MEDIA. Sawwa: Jurnal Studi Gender, 9(1), 159-178. https://doi.org/10.21580/sa.v9i1.671

Helmi, M. I. (2015). PENGADILAN KHUSUS KDRT "Implementasi Gagasan Sistem Peradilan Pidana Terpadu Penanganan Kasus-Kasus Kekerasan Terhadap Perempuan (SPPT-PKKTP)." JURNAL CITA HUKUM, 1(2), 317-330. https://doi.org/10.15408/jch.v1i2.1471

Jalil, A. (2010). Islamic Law of Contract is Getting Momentum, 1(2), 175-192.

Mardani. (2016). Hukum Keluarga Islam di Indonesia. Jakarta: Kencana.

Menendez, H. D. (2013). Abuse of Process. Xlibris Corporation.

Muhajarah, K. (2016). KEKERASAN TERHADAP PEREMPUAN DALAM RUMAH TANGGA: Perspektif Sosio-Budaya, Hukum, dan Agama. SAWWA, 11(2), 127-146.

Paymar, M. (2000). Violent No More: Helping Men End Domestic Abuse. Alameda: Hunter House.

Rakovec-Felser, Z. (2014). Domestic Violence and Abuse in Intimate Relationship from Public Health

Perspective. Health Psychology Research, 2(3), 62-67. https://doi.org/10.4081/hpr.2014.1821

Rheinstein, M., \& Glendon, M. A. (1980). International Encyclopedia of Comparative Law (Vol. IV). Leiden: BRILL.

Robila, M., \& Taylor, A. C. (2018). Global Perspectives on Family Life Education. Cham: Springer.

Sayeed, S. A., \& Prakash, A. (2013). The Islamic prayer (Salah/Namaaz) and yoga togetherness in mental health. Indian Journal of Psychiatry, 55(Suppl 2), S224-S230. https://doi.org/10.4103/0019-5545.105537

Shipway, L. (2004). Domestic Violence: A Handbook for Health Care Professionals. London-New York: Routledge.

Sondy, A. D. (2013). The Crisis of Islamic Masculinities. Lahore-New Delhi-NewYork-Sydney: A\&C Black.

Starrett, G. (1998). Putting Islam to Work: Education, Politics, and Religious Transformation in Egypt. Berkeley-Los Angles_London: University of California Press.

Statsky, W. P. (2012). Family Law. New York: Cengage Learning.

Stiles, E. (2009). An Islamic Court in Context: An Ethnographic Study of Judicial Reasoning. New York: Springer.

Tamam, A. M. (2017). ISLAMIC WORLD VIEW Paradigma Intelektual Muslim. Jakarta: Spirit Media Press.

Voorhoeve, M. (2012). Family Law in Islam: Divorce, Marriage and Women in the Muslim World. London-New York: I.B.Tauris.

Yarsley, K. (2014). The Instruction Manual for Kids - Parent'S Edition. Bloomington-Indianapolis: Balboa Press.

Yusdani. (2011). Menuju Fiqh Keluarga Progresif. Yogyakarta: Kaukaba. 